NBSIR 80-1964

\title{
Recommended Guidelines for Safety Inspection of Construction of Concrete Cooling Towers
}
H. S. Lew
S. G. Fattal
B. J. Hunt

Structures and Materials Division Center for Building Technology National Engineering Laboratory National Bureau of Standards Washington, D.C. 20234

January 1980

Issued February 1980

\section{Prepared for}

Occupational Safety and Health

$$
\text { Administration }
$$

Department of Labor

Washington, D.C. 20210 
$\because$

RECOMMENDED GUIDELINES FOR SAFETY INSPECTION OF CONSTRUCTION OF CONCRETE COOLING TOWERS
H. S. Lew
S. G. Fattal
B. J. Hunt

Structures and Materials Division

Center for Building Technology

National Engineering Laboratory

National Bureau of Standards

Washington, D.C. 20234

January 1980

Issued February 1980

Prepared for

Occupational Safety and Health

Administration

Department of Labor

Washington, D.C. 20210

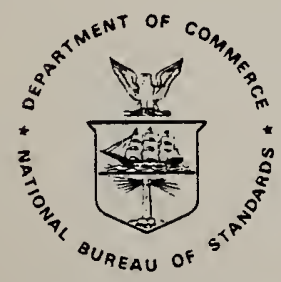

U.S. DEPARTMENT OF COMMERCE, Philip M. Klutznick, Secretary

Luther H. Hodges, Jr., Deputy Secretary

Jordan J. Baruch, Assistant Secretary for Science and Technology

NATIONAL BUREAU OF STANDARDS, Ernest Ambler, Director 
$\ldots$

간.

$+2+2+2$ 


\section{ABSTRACT}

As a result of a construction failure of a natural draft cooling tower at Willow Island, West Virginia, the National Bureau of Standards (NBS) reviewed existing Occupational Safety and Health Administration (OSHA) construction safety and health regulations and developed guidelines for use by the OSHA compliance officers for safety evaluation of reinforced concrete shell cooling tower construction.

The guidelines furnished are based on existing OSHA regulations, but highlight their application to this type of construction by pointing out critical construction operations, their related safety aspects, and needed compliance inspection procedures. Major regulatory provisions affecting the basic construction plans, safety aspects of design criteria and responsibilities, record keeping, and inspections are summarized. Special attention is given to construction loadings, construction sequences, hoisting systems, and personnel safety training.

Detailed identification is made of items relating to concrete inspection, concrete control, formwork operations, construction loadings, hoisting systems, and construction safety planning.

Key words: concrete; construction; cooling tower; formwork; hoisting system; regulations; safety; standards. 

Page

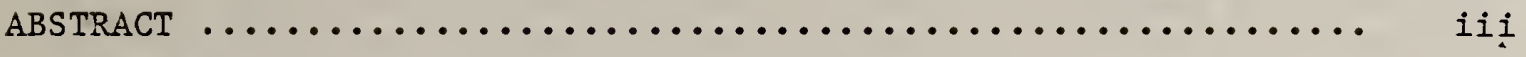

1. INTRODUCTION $\ldots \ldots \ldots \ldots \ldots \ldots \ldots \ldots \ldots \ldots \ldots \ldots \ldots \ldots \ldots \ldots \ldots$

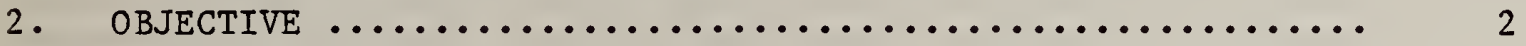

3. COOLING TOWER CONSTRUCTION $\ldots \ldots \ldots \ldots \ldots \ldots \ldots \ldots \ldots \ldots \ldots \ldots$

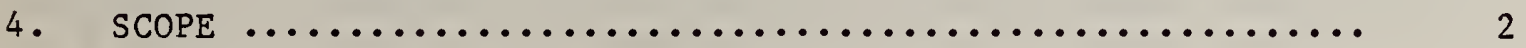

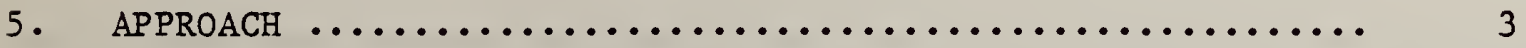

6. PRECONSTRUCTION PLAN REVIEW .................... 4

6.1 Basic Construction Plan Components ............... 4

6.1 .1 Design Loads for Construction ............. 5

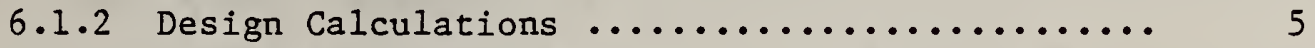

6.1.3 Criteria for Form Removal and Imposition of

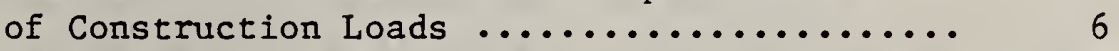

6.1 .4 Establishment of Benchmarks .............. 7

6.2 Personnel Training in Construction Operation ........ 7

7. INSPECTION TASKS DURING CONSTRUCTION PHASES $\ldots \ldots \ldots \ldots \ldots \ldots .7$

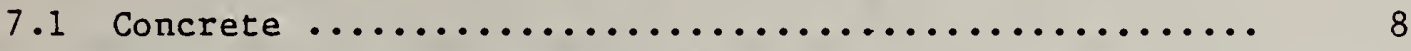

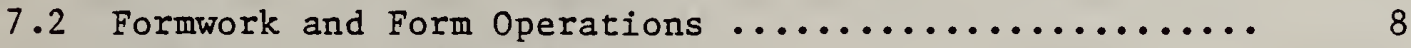

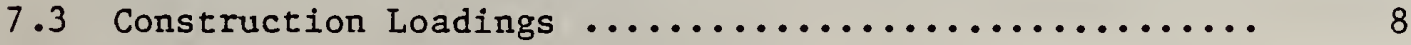

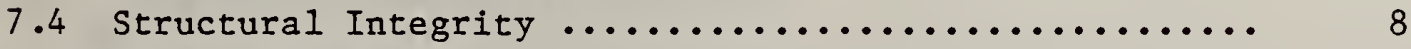

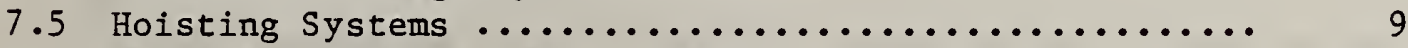

7.6 Detailed Personal Safety Checks .................. 10

8. MAINTAINING SAFETY RELATED RECORDS $\ldots \ldots \ldots \ldots \ldots \ldots \ldots \ldots \ldots$

APPENDIX A - COMPILATION OF PERTINENT EXCERPTS FROM OSHA REGULATIONS .......................... A -1 


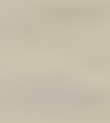


1 .

The construction of reinforced concrete structures in which the partially completed structure plays a key role in supporting construction workers and other construction loads presents special challenges to providing a safe working environment. In recent years, many innovative concepts to speed construction and minimize formwork have been introduced for the construction of cooling towers. Many of these construction schemes rely heavily on the strength of partially cured concrete to completely support the working platforms, formwork and other construction equipment and loads. Because partially completed concrete shell structures may be lacking in resistance to unforeseen concentrated loadings, an accident which might ordinarily be expected to cause relatively small damage could result in a major collapse of the elements supporting the work surface.

The Occupational Safety and Health Administration (OSHA) currently enforces existing construction safety regulations for general concrete construction. These regulations as conţined in existing Safety and Health Regulations for Construction of OSHA include important provisions for ensuring the safety of workmen in concrete construction. In some types of concrete construction the enforcement of these provisions requires considerable engineering insight and judgement.

As a result of the natural draft cooling tower construction disaster at Willow Island, West Virginia, April 27, 1978, the Center for Building Technology of the National Bureau of Standards (NBS) has reviewed existing construction safety and health regulations currently enforced by OSHA. This report presents recommended guidelines for use by the OSHA compliance officers for safety evaluation of reinforced concrete shell cooling tower construction. These guidelines are based on the existing OSHA Construction safety and Health Regulations, but highlight their application to reinforced concrete shell cooling tower construction by pointing out critical construction operations, their safety aspects, and check procedures to determine if safety regulations are being observed.

These guidelines emphasize those aspects of construction operations which can most readily endanger a large number of workmen through disastrous construction collaspes and are in addition to the more usual safety checks to ensure the maintenance of a safe working environment for individual workers. These guidelines suggest the use of OSHA specialists and

1 Department of Labor, Bureau of Labor Standards, "Safety and Health Regulations for Construction," (29 CFR Part 1926), Washington, D.C. 
engineering consultants to assist the local compliance officers in assessment if safety regulations are being observed.

\section{OBJECTIVE}

The objective of this report is to furnish OSHA compliance officers a guide to enforcement of current safety regulations as they apply to construction of reinforced concrete shell cooling towers. It specifically is intended to alert the compliance officer to the need to evaluate the critical safety elements of the overall construction scheme and to check for compliance with existing regulations designed to guard against large scale collapse during the construction process.

\section{COOLING TOWER CONSTRUCTION}

Construction techniques for large natural draft reinforced concrete thin shell cooling towers have evolved rapidly in the last two decades. These structures are usually a large tower with a diameter and wall thickness that change over the height of the tower. This necessitates constant adjustment of the forms and scaffolding to accomodate the geometric changes. Frequently, complex patented form systems are used to provide adjustments. In the early days of tower construction, support scaffolding often extended from the ground to the level where concrete was being placed. In more recent times, the forms and scaffolding have been suspended from previously completed portions of the structure and travel up the structure as construction continues. In some applications, free standing tower cranes are used to deliver materials to the construction level, while in other systems, holsting devices supported from the partially completed structure are used. The concrete tower is usually cast in consecutive segments which are concentric rings 1.3 to $2 \mathrm{~m}$ ( 4 to $6 \mathrm{ft}$ ) in height. Ordinarily, a complete circular ring is cast in a single day. Several systems utilize a 1-day sequence so that a new lift is cast each working day. These construction methods place significant construction loads at very early ages on partially matured, partially constructed structures. Some of these systems also place very significant hoisting loads on the partially constructed structure. These procedures must be carefully designed and controlled to ensure a safe working environment.

4. SCOPE

The recommended guidelines presented in this report are divided into two parts. The first part (Section 6 of this report) deals with 1tems which should be included in a safe construction plan. Items in this category should be evaluated prior to initiation of major construction or soon after construction commences. The second category (Section 7) deals with items which should be checked during inspections conducted after the cooling tower is in advanced stages of construction. In addition, building code regulations, that require the maintenance of safety inspection records 
are presented in Section 8. Appendix A contains a compilation of pertinent excerpts from the OSHA regulations.

All of the guidelines are based on the existing safety regulations of OSHA. These include:

\section{OSHA Standards}

1. 29 CFR 1926.20 - General safety and health provisions.

2. 29 CFR 1926.251 - Rigging equipment and material handling.

3. 29 CFR 1926.451 - Scaffolding.

4. 29 CFR 1926.550 - Cranes and derricks.

5. 29 CFR 1926.552 - Material hoists, personnel hoists, and elevators.

6. 29 CFR 1926.700 - General provisions for concrete, concrete forms and shoring.

7. 29 CFR 1926.701 - Forms and shoring.

\section{Reference Standards}

1. ANSI A10.5-1975 - Safety requirements for material hoists.

2. ANSI A10.8-1977 - Safety requirements for scaffolding.

3. AnSI Al0.9-1970 - Safety requirements for concrete construction and masonry work.

4. ASTM C31-69 - Standard method for making and curing concrete test specimens in the field.

5. ASTM C39-72 - Standard test method for compressive strength of cylindrical concrete specimens.

Frequent references to specific regulations are provided and a compilation of important provisions affecting construction of this type is provided in Appendix A.

\section{APPROACH}

For the construction of cooling towers, it is recommended that OSHA use a specialist-engineer/consultant to review the proposed construction plan for conformance with OSHA regulations preferably prior to initiation of major construction or soon after construction commences. If an OSHA 
specialist is not available, the OSHA field office should engage the services of a consultant to assist in review of the plan. The complex engineering aspects of the partially completed structure and the erection system indicate that any such consultant must be a registered engineer.

The specialist-engineer/consultant should brief the OSHA compliance officers on the key elements of the construction plan and suggest inspection techniques to check on these elements. The plan should contain specific "bench marks" against which the OSHA compliance officer can check compliance of critical tasks affecting the safety of the worker while construction is in progress.

The approach for subsequent inspections by OSHA compliance officers should be to first check the job site for overall conformance with the construction plan and, in particular, for proper observance of the "bench marks". The compliance officers will also have available to them detailed records of critical operations which are required to be kept by building code regulations. These can be checked to determine whether the "bench marks" are being regularly observed between visits. After general safety is inspected to ensure that the overall work surfaces are not in danger of collapse, then more routine individual related safety checks can be carried out.

\section{PRECONSTRUCTION PLAN REVIEW}

The effectiveness of OSHA safety regulations in maintaining a safe working environment during construction of cooling towers can be greatly improved by revlewing the basic construction plan in advance of the construction operations.

\subsection{Basic Construction Plan Component}

The OSHA regulations require that the contractor have the responsibility for providing a safe working environment for his workers [29 CFR 1926.20]. He is responsible that formwork is adequately designed, erected, supported, braced and maintained so that the formwork together with the partially completed structure will safely support all loadings including construction loads. [29 CFR 1926.701(a)(1) and ANSI Al0.9-6.1]. Since this general type of construction clearly should be classified as complex formwork, the formwork must be designed or approved for use by an engineer or experienced form designer [ANSI Al0.9-6.2.2]. The formwork must be planned in every particular and designed and constructed with an adequate factor of safety [AISI Al0.9-6.2.1]. Thus, to comply with these regulations, the contractor must have a comprehensive concrete construction plan with design, or approval for use, by an engineer or experienced form designer acting in his behalf.

The baslc construction plan should include, but not necessarily be limited to, the following specific items: 
a. Design loads for construction.

b. Design calculations.

c. Criteria for form removal and imposition of construction loads.

d. Establishment of bench marks for each stage.

\subsubsection{Design Loads for Construction.}

The loads used for design of the formwork and scaffolding systems should be clearly listed so that they can be checked readily when considering the imposition of loads not foreseen in the design or the plan. The loads considered in design should include:

1. Design loads of construction materials.

2. Dead loads of formwork and scaffolds.

3. Dead loads of hoisting systems.

4. Live loads for workers.

5. Live loads for hoisting systems plus impact.

6. Live loads for equipment plus impact.

7. Lateral loads for wind, cable tension, inclined support, impact of concrete placement, starting and stopping of equipment.

When a partially completed and partially matured concrete shell structure is to be subjected to construction loads, the regulations require that the contractor must confirm that the shell is designed specifically to support such loads and must acquire approval for the application of such loads from the engineer/architect [29 CFR 1926.701(a)(4) and ANSI A10.9-6.3.4].

\subsubsection{Design Calculations}

Design calculations for the formwork system, the hoisting system, and all components shall be made available at the job site [ 29 CFR 1926.701(a)(2)]. These calculations may be used to assess compliance with regulations pertaining to construction safety. Included in these are the design of formwork, scaffolding, and hoisting assemblies, minimum strength of concrete required for different phases of construction operation and the design of any other equipment or structural component used in the construction work. 
For ease of reference, the design calculations for the formwork and scaffolding systems and other supporting elements should list critical items which were considered in the design. These may include, but are not limited to, the following items:

a. Loading conditions.

b. Load factors or safety factors.

c. Design unit stresses and material grades.

d. Reuse criteria for forms and associated design unit stresses.

e. Safety factors used for form accessories.

f. Any special provisions considered in the design.

\subsubsection{Criteria for Form Removal and Imposition of Construction Loads}

A key operation affecting worker safety is form removal and relocation. Criteria for stripping concrete forms and moving falsework shall be set by an engineer [ANSI Al0.9-6.4.7]. In addition, specific provisions for testing field cured concrete cylinders prior to removal of forms is addressed. This requirement is a means of preventing premature removal of forms (i.e., before the specified strength needed for the support of construction loads is achieved). This is one of the most critical safety related provisions in cooling tower construction.

The life safety of a large number of workers is directly dependent on the structural integrity of partially cured concrete which is used to support the formwork, scaffolds, various assemblies and the personnel involved in the casting operations. This support system must not be susceptible to initiation of a chain reaction collapse if a small part is damaged by a minor accident. The incomplete provision for premature removal of important elements can make some systems extremely susceptible to such chain reactions. OSHA regulations require that the engineer's specifications and local building codes be followed for form removal [ANSI A10.9-6.4.7] and require specific approval for the imposition of construction construction loads on the partially completed structure by the engineer-architect responsible for the design of the structure [29 CFR 1926.701 (a)(4) and ANSI A10.9-6.3.4]. This approval will usually consist of setting certain minimum concrete strengths which must develop before various operations can commence. There may be different values for different types of construction operations and loadings (one value for form removal, another for form movement, another for hoist loading, etc.). 


\subsubsection{Establishment of Bench Marks}

The key for practical enforcement is the "bench mark" which indicates a specific measurement or check which may be used by the OSHA compliance officer to affirm whether critical safety procedures are being adhered to during the construction process. These "bench marks" are predetermined norms against which job records and other supplementary information acquired from independent observations in the field can be compared to ensure that safe construction practices are being followed.

Typical bench marks may include:

a. Minimum concrete strength for form removal.

b. Minimum concrete strength for falsework movement.

c. Minimum concrete strength for operation of hoisting devices attached to or supported by the partially completed structure.

d. Minimum concrete strength for placement of new concrete.

e. Number, size, and location of fastenings, ties, anchor devices or other supports required so that the falsework and forms perform safely at each stage of construction.

f. Criteria to be met before removal or relocation of any fastenings, ties, anchor devices or other supports.

g. Maximum hoisting load and maximum operating speed.

h. Minimum hoist clearance and size of sheaves.

i. Size of cables and sheaves.

\subsection{Personnel Training In Construction Operation}

An awareness of the critical safety aspects of the operations by all employees in the field will be a key factor in reducing the risk of catastrophic construction failures.

Training and education of personnel in safe conduct of work is part of OSHA safety regulations [29 CFR 1926.20 and 29 CFR 1926.21(b)(2)] - A detailed procedure manual for use in training personnel in safe operations should be developed as part of the basic construction plan. The manual should spell out the sequence of key operations, the number and sequence of attachments, key limits for decisions on major operations, safety checks, periodic inspection of safety-related ifems and any other action that can be foreseen and that would prevent unsafe situations from developing during the operations. Key personnel shall be thoroughly trained in this plan and all personnel should have basic knowledge of important details. Having 
this key information on record will enable the OSHA compliance officers to conduct their field investigations with regard to safety education of personnel.

The supervisors, lift equipment operators, and the material hoists operators shall be trained for the operations of their particular system and shall be particularly knowledgeable with regard to the critical safety aspects of the overall construction plan.

An important element of this task is the training of inexperienced workers as well as job orientations of other workers not previously engaged in cooling tower construction operations.

\section{INSPECTION TASKS DURING CONSTRUCTION PHASE}

In cooling tower construction the OSHA compliance officer must check the overall safety of the working place as well as the detailed personal safety requirements normally applicable to all construction.

The nature of this type of construction requires certain specific types of checks which involve construction operations that are critical to the maintenance of safety. These are covered in the following sections.

\subsection{Concrete}

The development of concrete strength is affected primarily by mix proportions of material ingredients, age, and curing temperature. Particularly, in cold weather, concrete gains strength slowly. Special curing, such as steam curing, can accelerate strength gain. Certain types of cements and admixtures will slow down strength development while other types will accelerate strength development. Concrete strength therefore cannot be determined by visual inspection or by "tradition". The safety of formwork operations often depends almost completely on the concrete having reached certain strength values. These values should be clearly indicated as "bench marks."

On job-site inspections, the records of tests of field cured (not laboratory cured) concrete specimens should be checked to determine that specimens were tested prior to formwork removal or other key construction operations and that the minimum strengths required (bench marks) were met. Failure to meet these requirements is a severe violation of ANSI Al0.9-6.4.7 and imposes great risks on the working force.

\subsection{Formwork Operations}

Each Individual construction system will have a series of key attachment requirements and construction operation sequences. "Bench marks" should be established to identify these critical factors. Records for form placement, removal and other construction operations should be checked to 
determine that requirements are being followed. These should be cross checked with materials test records to see that proper strength was developed before operations were carried out. Visual inspection of current operations should be carried out to determine that all key equipment and operations are in accordance with the construction plan. Particular attention should be given to the number, location, and sequencing of attachment and anchor devices which support the traveling forms and scaffolding.

\subsection{Construction Loadings}

The construction loadings for which the construction system has been designed should be outlined in the construction plan. Visual inspection should be made to determine if additional construction loadings are being imposed. Extra equipment, material stockpiles, excess hoist loads created by hurried operations can cause excessive construction loadings.

\subsection{Structural Integrity}

If the construction operations are being supported by the partially completed structure, the OSHA compliance officer must be concerned with the integrity of the support structure. If signs of structural inadequacy are present a structural engineering specialist should be consulted.

Such items as severe honeycombing of concrete, exposed reinforcement, omission of reinforcement, severe cracking, gross tolerances, or crumbling concrete indicate potential distress.

\subsection{Hoisting System}

Overall safety requirements for material and personnel hoists are specified in 29 CFR 1926.552 and ANSI A10.5. In addition, the hoisting system and its interaction with the construction system and the partially completed structure should be checked. Signs of severe impact can indicate overload on the support structure. Failure of a hoist wire rope can cause severe consequences if the payload then impacts the scaffolding, formwork, or support structure.

Detailed inspection records for all hoisting machinery should be checked [29 CFR 1926.550(a)]. Specific checks should be made to determine that required daily visual inspections of hoisting machinery are being performed and manufacturers' specifications adhered to [ANSI A10.5-16.19]. A thorough annual inspection of the hoisting machinery shall be performed by a competent person or a government or private agency recognized by the U.S. Department of Labor. The employer shall maintain records of dates and results of inspections for each hoisting machine and piece of equipment. The following highlight the various ANSI inspection specifications: 
ANSI 10.5-14.2.1 - Period of inspection is defined.

29 CFR $1926.25(a)(1)$

ANSI Al0.5-14.2.2 - Method of wire rope inspection is defined.

ANSI Al0.5-14.3.1 - Criteria for wire rope removal and replacement is given.

ANSI Al0.5-14.4 - Requirements for wire rope installation are given.

After the wire rope has been in use for a maximum of one month, all nuts on all wire rope clips shall be retightened to the manufacturers' torque recommendations [ANSI 10.5-15.3]. The minimum number of clips, spacing of clips and torque tightening of clips shall conform to manufacturers' recommendations [ANSI 10.5-15.2].

All drums and sheaves shall conform to ANSI 10.5, Sections 14.5 .1 through 14.5 .13 .

Electrical communication during hoist operations shall conform to ANSI 10.5, Section 19.0. The OSHA compliance officer shall inspect the communication systems according to a preestablished "bench mark" to ensure compliance.

Records of the designated inspections and conclusive findings shall be maintained at the job site by the designated inspector and made available to the OSHA compliance officer.

\subsection{Detailed Personal Safety Checks}

After the OSHA compliance officer has checked the construction-erection procedures critical to the support of work surfaces for which failure might result in multiple injuries and fatalities, he should proceed with more detailed and routine checks for compliance with regulations whose violation might result in injury to a single worker or a small group of workers.

\section{MAINTAINING SAFETY-RELATED RECORDS}

Current bullding code provisions (ACI $318-77^{2 /}$, Section 1.3 and 3.1 ) require important construction and safety records, which are vital for the OSHA Inspection of overall construction safety, be kept during progress of work and for two years after completion of work. In addition, these

${ }^{2}$ Building Code Requirements for Reinforced Concrete, ACI 318-77, American Concrete Institute, Detroit, Michigan. 
provisions require that all concrete construction shall be inspected

throughout the various work stages by a competent engineer or architect, or their competent representative normally representing the owner. Thus a designated inspector must maintain a record which covers many items which can indicate if construction is in accordance with the construction plan. Some of the key items required by ACI 318-77 Sections 1.3 and 3.1 include:

a. Maintaining records for quality, proportions, mixing, placing and curing concrete.

b. Maintaining detailed temperature and curing records in cold and hot weather.

c. Maintaining records for reinforcing placement, form placement and removal.

d. Maintaining records for any significant construction loadings on completed walls.

e. Maintaining a complete record of tests of materials including concrete.

The contractor should identify individuals who are responsible for inspecting and maintaining the records of these items.

Since ANSI A10.9-6.4.7 requires that tests shall be made on field-cured concrete specimens prior to form removal, records of these early age concrete tests must be maintained as well as the more usual 28-day tests to determine quality of the mature concrete. These records should be checked against the "bench mark" values from the construction plan. 



\section{APPENDIX A}

\section{CONTENTS}

A.1 Excerpts from Safety and Health Regulations for Construction 29 CFR Part 1926, Bureau of Labor Standards, Department of Labor, Washington, D.C., June 24, 1974.

A.2 Excerpts from Safety Requirements for Material Hoists, American National Standard ANSI A10.5-1975, American National Standards Institute, New York, New York.

A.3 Excerpts from Safety Requirements for Concrete Construction and Masonry Work, American National Standard ANSI Al0.9-1970, American National Standards Institute, New York, New York. 


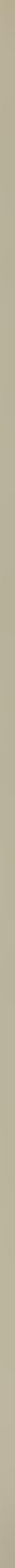


A.1 Excerpt from

Safety and Health Regulation

for Construction,

29 CFR Part 1926

Bureau of Labor Standards

Department of Labor

Washington, D.C.

June 24, 1974 


\subsection{General safely and health provisione.}

(a) Contractor requirements. (1) Section 107 of the Act requires that it shall be a condition of each contract which is entered into under legislation subject to Reorganization Plan Number 14 of 1950 (64 Stat. 1267), as defined in \$1926.12. and is for construction, alteration, and/ or repair, including painting and decorating. that no cuntractor or subcontractor for any part of the contract work shall require any laborer or mechanic employed in the performance of the contract to work in surroundings or under working conditions which are unsanitary. hazardous, or dangerous to his health or sarety.

(b) Acctdent prevention responsibillthes. (1) It shall be the responsibility of the employer to Initiate and maintain such programs as may be necessary to comply with this part

(2) Such programs shall provide for irequent and regular inspections of the Job sites, materials, and equipment to be made by competent persons designsted by the emplosers.

(3) The use of any machiners, tool material, or equipment which is not in compliance with any applicable requirement of this part is probibited. Such machine. tool. materlal, or equipment shall elther be Identifled as unsafe by tagging or locking the controls to render them inoperable or shall be phrsically removed from its place of operation.

(4) The employer shal permit onf those employees qualliled by training or experience to operate equipment and machiners.

8 192621 Safety training and edacation.

(a) General requirements. The Secretary shall, pursuant to section $107(f)$ of the Act, establish and superrlse proprams for the education and training of employers and employees in the recognition. avoidance and prevention of unsafe conditions in employments covered by the act.

(b) Employer responstbitity. (1) The employer should arail himself of the safety and health training prosrams the Secretary provides.

(3) The employer shall Instruct each employee in the recognition and avoidance of unsafe conditions and the regulations applicable to his port enfironment to control or eliminate any hazards or other exposure to illness or injury.
§ 1926.251 Rigging equipment for material handling.

(a) General. (1) Rigging equipment for material handling shall be inspected prior to use on each shift and as necessary during its use to ensure that it is safe. Defective rigging equipment shall be removed from service.

(2) Rlgging equipment shall not be loaded in excess of its recommended safe workdng load, as prescribed in Tables $\mathrm{H}-1$ through $\mathrm{H}-20$ in this subpart. followlng \& 1926.252(e) for the speciflc equipment.

(3) Rigging equipment, when not in use, shall be removed from the immediate work area so as not to present a hazard to employees.

(4) Special custom design grabs, hooks, clamps, or other lifting accessoHes, for such units as modular panels, prefabricated structures and similar materfals, shall be marked to inoicate the safe working loads and shall be proottested prior to use to 125 percent of thels rated load.

(b) Alloy steel chains. (1) Welded alloy steel chain silngs shall have permanently afflxed durable identification stating size, grade, rated capacity, and sling manufacturer.

(2) Hooks, rings, oblong links, pearshaped links, welded or mechanlcal coupling links, or other attachments, when used with alloy steel chains, shall have a rated capacity at least equal to that of the chain.

(3) Job or shop hooks and Hnks, or makeshift fasteners, formed from bolts, rods, etc., or other such attachments, shall not be used.

(4) Rated capacity (working load limit) for alloy steel chatn slings shall conform to the values shown in Table H-1.

(5) Whenever wear at any point of any chain link exceeds that shown in Table $\mathrm{H}-2$, the assembly shall be removed from service.

(c) Wire rope. (1) Tabies $\mathrm{H}-3$ through $\mathrm{H}-14$ shall be used to determine the safe working loads of various sizes and classtfications of lmproved plow steel wire rope and wire rope slings with various types of terminals. For sizes, classiflcstions, and grades not included in these tables, the safe working load recommerded by the manufacturer'for speciflc, identiflable products shall be followed, provided that a safety factor of not less than 5 is maintained. 

(2) Protruding ends of strands in splices on slings and bridles shall be covered or blunted.

(3) Wire rope shall not be secured by knots, except on haul back lines on scrapers.

(4) The following limitations shall apply to the use of wirc rope:

(1) An eye splice made in ang wire rope shall have not less than three full tucks. Eowever, this requirement shall not operate to preclude the use of another form of splice or connection whicb can be shown to be as efflelent and which is not otherwise prohibited.

(ii) Except for eye splices in the ends of wires and for endless rope slings, each wire rope used in holsting or lowering, or in pulling loads, shall consist of one continuous plece without knot or splice.

(iii) Ejes in wire rope bridles, slings, or bull wires shall not be formed by wire rope clips or knots.

(iv) Wire rope shall not be used if, in ans length of elght diameters, the total number of visible broken wires exceeds 10 percent of the total number of wires, or if the rope shows other signs of exeessive wear, corrosion, or defect.

(5) When U-bolt wire-rope clips are used to form eyes, Table $\mathrm{H}-20$ shall be used to determine the number and spacing of clips.

(i) When used for eye splices, the $U$-bolt shall be applied so that the "U" section is in contact with the dead end of the rope.

(d) Natural rope, and synthetic fiber(1) General. When using natural or synthetic fiber rope slings. Tables H-15, 16 , 17 , and 18 shall apply.

(2) All splices in rope slings provided by the employer shall be made in accordance with fiber rope manufacturers recommendations.

(1) In manila rope, eye splices shall contaln at least three full tucks, and short splices shall contaln at least six full tucks (three on each side of the centerline of the splice).

(11) In layed synthetlc fiber rope, eye spilces shall contalo at least four full tucks, and short splices shall contaln at least eight full tucks (four on each side of the centerline of the splice). (iii) Strand end taus shall not be trimmed short (flush with the surface of the rope) immediately adjacent to the full tucks. This precaution applies to both eye and short splices and all types of flber rope. For fiber ropes under 1 -inch diameter, the tails shall project at least six rope diameters beyond the last full tuck. For fiber ropes 1-inch diameter and larger, the talls shall project at least 6 inches beyond the last full tuck. In applications where the projecting tails may be objectionable, the talls shall be tapered and spliced into the body of the rope using at least two additional tucks (which will require a tail length of approximately $3 \mathrm{ix}$ rope diameters beyond the last full tuck).

(iv) For all eye splices, the eye shall be sufficiently large to provide an included angle of not greater than $60^{\circ}$ at the splice when the eye is placed over the load or support.

(v) Knots shall not be used in lleu of splices.

(e) Synthetic webbing (nylon, polyester, and polypropylene). (1) The employer shall have each synthetlc web sling marked or coded to show:

(1) Name or trademark of manufacturer.

(ii) Rated capacities for the type of hitch

(iii) Type of material.

(2) Rated capacity shall not be exceeded.

(f) Shackles and hooks. (1) Table F-19 shall be used to determine the safe working loads of various sizes of shackles, except that higher safe working louds are permissible when recommended by the manufacturer for specific, identifiable products, provided that a safety factor of not less than 5 is maintained.

(2) The manufacturer's recommendations shall be followed in determining the safe working loads of the various sizes and types of specific and identifiable hooks. All hooks for which no applicable manufacturer's recommendations are available shall be tested to twice the intended safe working loar before they are initially put into use. The employer shall maintain a record of the dates and results of such tests. 

\$1926.451 Scaffolding.

(a) General requirements. (1) Scapfolds shall be erected in accordance with requirements of this section.

(2) The footing or anchorage for scasfolds shall be sound, rigid, and capable of carrying the maximum intended load without settling or displacement. Onstable objects such as barrels, boxes, loose brick, or concrete blocks, shall not be used to support scaffolds or planks.

(3) No scaffold shall be erected, moved, dismantled, or altered except under the supervision of competent persons.

(4) Guardrails and toeboards shall be installed on all open sides and ends of platforms more than 10 feet above the ground or floor, except needle beem scasfolds and floats (see paragraphs $(p)$ and (w) of this section). Scaffolds 4 feet to 10 feet in helght, baving a minimum horizontal dimension in efther direction of less than 45 inches, shall have standard guardrails installed on all open sides and ends of the platform.

(5) Guardralls shall be $2 \times 4$ inches, or the equivalent, approximately 42 Inches high, with a midrall, when required. Supports shall be at intervals not to exceed 8 feet. Toeboards shall be a minimum of 4 inches in height.

(6) Where persons are required to work or pass under the scaffold, scaffolds shall be provided with a screen between the toeboard and the guardrail, extending along the entire opening, consisting of No. 18 gauge U.S. Standard wire $1 / 2$ inch mesh, or the equivalent.

(7) Scaffolds and their components shall be capable of supporting without failure at least 4 times the maximum intended load.

(8) Any scaffold including accessories such as braces, braclets, trusses, screp legs, ladders, etc. damaged or weakened from any cause shall be lmmediately repaired or replaced.

(9) All load-carrying tímber members of scaffold framing shall be a minimum of 1,500 fiber (Stress Grade) construction grade lumber. All dimensions are nominal sizes as provided in the Amertcan Lumber Standards, except that where rough sizes are noted, only rough or undressed lumber of the size speciffed Fill satisfy minimum requirements.
(10) All planking shall be Scaffold Grades, or equivalent, as recognized by approved grading rules for the species of wood used. The maximum permissible spans for 2- $x$ 10-inch or wider planks shall be as shown in the following:

\section{TABLE Im-3}

MATERLA

\begin{tabular}{|c|c|c|c|c|c|}
\hline \multirow[b]{2}{*}{$\begin{array}{l}\text { Torklog load (p.s.f.) } \\
\text { Permissible span (ft.) }\end{array}$} & \multicolumn{3}{|c|}{$\begin{array}{l}\text { Full thlckosess } \\
\text { andressed } \\
\text { lumber }\end{array}$} & \multicolumn{2}{|c|}{$\begin{array}{l}\text { Nominal } \\
\text { thlckness } \\
\text { lumber I }\end{array}$} \\
\hline & $\begin{array}{l}25 \\
10\end{array}$ & $\begin{array}{r}80 \\
8\end{array}$ & $\begin{array}{r}78 \\
6\end{array}$ & $\frac{25}{8}$ & $\begin{array}{r}80 \\
6\end{array}$ \\
\hline
\end{tabular}

1 Nominal thlckoess lamber not recommended for bespy duty use.

(11) The maximum permissible span for 11/4- x 9-inch or wider plank of full thickness shall be 4 feet with medium duty loading of 50 p.s.t.

(12) All planking of platforms shall be overlapped (minimum 12 inches), or secured from movement.

(13) An access ladder or equivalent safe access shall be provlded.

(14) Scaffold planks shall extend over their end supports not less than 6 inches nor more than 12 inches.

(15) The poles, legs, or uprights of scaffolds shall be plumb, and securely and rigidly braced to prevent swaying and displacement.

(16) Overhead protection shall be provided for men on a scafiold exposed to overhead hazards.

(17) Slippery conditions on scaffolds shall be eliminated as soon as possible after they occur.

(18) No welding, burning, riveting, or open flame work shall be performed on any staging suspended by means of fiber or synthetic rope. Only treated or protected fiber or syntbetic ropes shall be used for or near any work involving the use of corrosive substances or chemicals. Specific requirements for boatswain's chairs and float or ship scaffolds are contained in paragraphs (1) and (w) of this section.

(19) Wire, syrathetic, or fiber rope used for scaffold suspension shall be capable of supporting at least 6 times the rated load.

(20) The use of shore or lean-to scaffolds is prohtbited.

(21) Lumber sizes, when used in this subpart, refer to nominal sizes except where otherwise stated. 

(g) Outrigger scafolds. (1) Outrigger beams shall extend not more than 6 feet beyond the face of the building. The inboard end of outrigger beams, measured from the fulcium point to anchorage point, shall be not less than $11 / 2$ times the outboard end in length. The beams shall rest on edge, the sides shall be plumb, and the edges shall be horfzontal. The fulcrum point of the beam shall rest on a secure bearing at least 6 inches in each hortzontal dimension. The beam shall be secured in place against movement and shall be securely braced at the fulcrum point agalnst tipping.

(2) The inboard ends of outrigger beams shall be securely anchored el ther by means of struts bearing against sllls in contact with the overhead beams or celling, or by means of tension members secured to the floor joists underfoot, or by both if necessary. The Inboard ends of outrigger beams shall be secured sgalnst tipping and the entire supporting structure shall be securely braced in both directions to prevent any horizontal movement.

(3) Unless outrigger scaffolds are designed by a registered professional engineer competent in this fleld, they shall be constructed and erected in accordance with Tabie I-13. Outrigger scaffolds, designed by a registered professional engtneer, shall be constructed and erected in accordance with such design.

\begin{tabular}{|c|c|c|}
\hline \multirow{2}{*}{$\begin{array}{l}\text { Madmum scaffold } \\
\text { load. }\end{array}$} & Light duty & Modium duty \\
\hline & \multicolumn{2}{|c|}{25 pest.......... 80 p.s.1. } \\
\hline 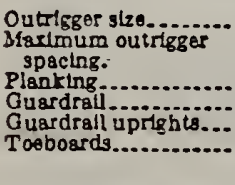 & $\begin{array}{l}2 \times 10 \ln \\
10 \mathrm{tt} 0 \mathrm{ln} \\
2 \times 10 \mathrm{l0} \\
2 \times 4 \mathrm{ln} \\
2 \times 1 \mathrm{ln} \\
4 \mathrm{ln} .(\mathrm{m} \mathrm{in} \\
\text { mum }\end{array}$ & 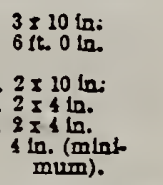 \\
\hline
\end{tabular}

(4) Planking shall be laid tight and shall extend to within 3 inches of the bullding wall. Planking shall be secured to the beams.

(5) Guardrails made of lumber, not less than $2 \times 4$ inches (or otber matertal provlding equivalent protection), approximatels 42 lnches bigh, with a midrall of 1 × 6 inch lumber (or other $\mathrm{ma}$ terial provlding equivalent protection) and toeboards, shall be lnstalled at all open sides and ends on all scaffolds more than 10 feet above the ground or floor. Toeboards shall be 8 minimum of 4 inches in height. Wire mesh shall be installed in accordance with paragraph (a) (6) of this section.
§ 1926.552 Material hoists, personnel hoists, and elevators.

(a) General requirements. (1) The employer shall comply with the manufacturer's specifications and limitations applicable to the operstion of all holsts and elevators. Where manufacturer's specifications are not available, the $\mathrm{llm}$ itations assigned to the equipment shall be based on the determinations of a professional engineer competent in the fleld.

(2) Rated load capacities, recommended operating speeds, and speclal hazard warnings or instructions shall be posted on cars and platforms.

(3) Wire rope shall be removed from service when any of the following conditions exists:

(i) In boisting ropes, six randomly distributed broken wires in one rope lay or three broken wires in one strand in one rope lay:

(ii) Abrasion, scrubbing, flattening, or peening, causing loss of more than anethird of the original diameter of the outside wires:

(iti) Evidence of any heat damage resulting trom a torch or any damage caused by contact with electrical wires;

(tv) Reduction from nominal diameter of more than three sixty-fourths inch for diameters up to and including three-fourths inch; one-sixteenth inch for diameters seven-eighths to $11 / 8$ Inches; and three thirty-seconds inch for dameters $11 / 4$ to $11 / 2$ inches.

(4) Elsting ropes shall be installed in accordance with the wire rope manufacturer's recommendations.

(5) The installation of live booms on holsts is prohibited.

(6) The use of endless belt-type manufts on construction shall be prohibited. (b) Material hoists. (1) (i) Operating rules shall be established and posted at the operator's station of the holst. Such rules shall loclude signal system and allowable line speed for various loads. Rules and notices shall be posted on the car frame or crosshead in a conspicuous location, including the statement "No Riders Allowed."

(11) No person shall be allowed to Idde on material hoists except for the purposes of inspection and maintenance.

(2) All entrances of the holstways shall be protected by substantial gates or bars which shall guard the full width of the landing entrance. All holstway entrance bars and gates shall be painted with diagonal contrasting colors, such as black and yellow stripes.

(1) Bars shall be not less than 2- by 4-Inch wooden bars or the equivalent, located 2 leet from the holstway line. Bars shall be located not less than 38 

inches nor more than 42 inches above the flloar.

(ii) Gates or bars protecting the entrances to hoistways shall be equipped with a latehing derice.

(3) Overhead protective covering of 2-trach plandeng. $3 / 4$-inch plswood, or other solld material of equitralent strength, shail be provided on the top of every material hoist cage or platform.

(4) The operator's station of a hoisting machine shall be provided with overhead protection equiralent to tight planking not less than 2 lnches thick The support for the orerhead protection shall be of equal strength.

(5) Hoist towers may be used with or without an enclosure on all sides. However, whichever alternative is chosen, the following applicable conditions shall be met:

(1) When a hoist tower is enclosed, it shall be enclosed on all sides for its entire height pith a screen enclosure of $1 / 2$-inch mesh, No. 18 J.S. gauge wire or equivalent, except for landing access.

(ii) When a hoist tower is not enclosed, the hoist platform or car shall be totally enclosed (caged) on all sldes for the full height between the floor and the orerhead protective covering with $1 / 2$ inch mesh of No. 14 U.S. gauge pire or equivalent. The hoist platiorm enclosure shall include the required gates for loading and unloading. A 6-foot hizh enclosure shall be provided on the unused sides of the hoist tower at ground level.

(6) Car arresting devices shall be tostalled to function in case of rope failure.

(7) All materfal holst towers shall be designed by a licensed professional engtneer.

(8) All material holsts shall conform to the requirements of ANSI A10.5-1969, Safety Requirements for Materlaj Hoists.

\$ 1926:553 Base-mounted drum hoists.

(a) General requirements. (1) Bxposed moving parts such as gears, projecting screws, setscrews, chain, cables, chain sprockets, and reciprocating or rotating parts, which constitute a hazard. shall be guarded.

(2) All controls used during the normal operation cycle shall be located within easy reach of the operator's station.

(3) Electric motor operated hoists shall be provided with:

(i) A device to disconnect all motors from the line upon power fallure and not permit any motor to be restarted untul the controller handle is brought to the "off" position:

(ii) Where appllcable, an overspeed preventive device: (11i) A means whereby remotels operated holsts stop when any control is ineffective.

(4) All base-mounted drum holsts in use shall meet the applicable requirements for design, construction, installation, testing. inspection, maintenance, and operations, as prescribed by the manufacturer.

Subpart Q-Concrete, Concrete Forms, and Shoring

§ 1926.700 General provisions.

(a) General. All equipment and materals used in concrete construction and masonry work shall meet the applicable requirements for design, construction, inspection, testing, maintenance and operations as prescribed in ANSI A10.9-1970, Safety Requirements for Concrete Construction and Masonry Work.

\$ 1926.701 Forms and shoring.

(a) General provisions. (1) Formwork and shoring shall be designed. erected, supported, braced, and maintalned so that it will safely support all vertical and lateral loads that may be imposed upon it during placement of concrete.

(2) Drawings or plans showing the fack layout, formwork, shoring, working decks, and scaffolding, shall be avallable at the Jobsite.

(3) Stripped forms and shoring shall be removed and stockplled promptir after stripping, in ail areas in which persons are required to worls or pass. Protruding nafls, wire ties, and other form sccessories not necessary to subsequent work shall be pulled, cut, or other means taken to eliminate the hazard.

(4) Imposition of ang construction loads on the partially completed structure shall not be permitted unless such loading has been considered in the design and approved by the engineerarchitect. 
A.2 Excerpts ${ }^{\star}$ from

Safety Requirements for Material Hoists

American National Standard ANSI A10.5-1975

American National Standards Institute

New York, New Yurk

* The Excerpts from ANSI AI0.5-1975 are reproduced herin by permission of the American National Standards Institute, New York, New York 10018. 


\section{American National Standard Safety Requirements for Material Hoists}

\section{General}

1.1 Scope. This standard applies to material hoists used to raise or lower materials during construction, alteration, or demolition. It is not applicable to the temporary use of permanently installed personnel elevators as material hoists.

1.1.1 This standard shall not apply to:

(1) Elevators constructed and operated in conformance with American National Standard Safety Code for Dumbwaiters, Escalators, and Moving Walks, A17.1-1971, including Addenda A17.1a-1972, A17.1b1973, and A17.1c-1974

(2) Personnel hoists constructed and operated in conformance with American National Standard Safety Requirements for Personnel Hoists, A10.41973

(3) Manlifts constructed and operated in conformance with American National Standard Safety Standard for Manlifts, A90.1-1969, including Supplement A90.1 a-1972

1.2 Purpose. This standard is designed to provide protection for those engaged in occupations requiring the use of material hoists and sets forth the minimum requirements for that purpose.

1.3 Exceptions. In cases of practical difficulties, unnecessary hardships, or new developments, exceptions to the literal requirements may be granted by the enforcing authority to permit the use of other devices or methods, but only when it is clearly indicated that equivalent protection is thereby secured.

\section{Related Standards}

2.1 General. This standard is intended for use in conjunction with the standards listed in 2.2 and 2.3.

\subsection{American National Standards (See Section 24) ${ }^{1}$}

American National Standard Safety Requirements for Scaffolding, A10.8-1969

\footnotetext{
'Availabie from American National Standards Institute, Inc, 1430 Broadway, New York, N.Y. 10018.
}

American National Standard Safety Standard for Mechanical Power Transmission Apparatus, B15.1-1972

American National Standard National Electrical Code, C1-1971 (NFPA No. 70-1971)

American National Standard Installation of Portable Fire Extinguishers, Z112.1-1974 (2nd ed) (NFPA No. 10-1974)

\subsection{American Institute of Steel Construction ${ }^{2}$}

AISC S310, Specification for the Design, Fabrication, and Erection of Structural Steel for Buildings, Feb 12, 1969

\section{Definitions}

In this standard the following definitions shall apply:

approved. Accepted as satisfactory by a duly constituted administrative or regulatory authority.

bucket. A metal container attached to the cage or cage frame and used to distribute concrete or other materials to various elevations.

cage/car. The load-carrying unit, consisting of a platform, a top, and a full or partial side enclosure.

car-arresting device. A device that will stop and hold the car with its rated load in the event of the failure of the wire rope, rack, pinion, or other car suspension means.

cathead. The structure for the support of the overhead sheaves.

equivalent. Denotes an alternate design, feature, device, or protective action that provides an equal degree of safety.

gross load (static load). The maximum load imposed on all rope by the platform, cage, car, or bucket and its rated load.

\footnotetext{
${ }^{2}$ Available from American Institute of Steel Construction, 101 Park Avenue, New York, N.Y. 10017.
} 

hoistway. A temporary shaftway - the space traveled by the platform or bucket.

hoistway enclosure. The structure that isolates the hoistway from all other parts of the building and on which the hoistway doors or gates and door or gate assemblies are installed.

inside hoists. Hoistways contained entirely within the building being served and which sometimes use the building structure itself for the support of the top beams, guide rails, and appurtenant parts necessary for the proper functioning of the platform.

live/luffing boom. A boom that does not operate on a fixed radius and is capable of vertical movement.

mast (tower). A vertical structure that supports and guides the platforms or buckets (and the counterweight, when used) on the outside of the mast structure.

material hoist. A mechanism for use in connection with the hoisting of construction or demolition materials. It is equipped with a platform, car, cage, or bucket that moves vertically on guide members.

platform. The load-carrying unit, including the frame, that directly supports the load.

rated load. The maximum live load for which the hoist structure is designed to operate.

rope. Refers to wire rope only.

shall. The word "shall" is to be understood as mandatory.

should. The word "should" is to be understood as advisory.

tower. A vertical structure that supports and guides the platforms or buckets (and the counterweight, when used) within or on the tower structure.

\section{Requirements for Hoist Towers}

4.1 Construction. Structural members of material hoist towers shall be constructed of strong, sound timber, steel, or other structural materials.

4.2 Initial Inspection. Before the hoist is placed in service, and each time after the tower is extended, all parts of the tower or mast, cage, bucket, boom, platform, hoisting machine, guys, and other equipment shall be thoroughly inspected by qualified and competent personnel.

4.3 Periodic Inspection. All sheaves, racks and pinions, guy ties, bolt connections, miscellaneous clamps. braces, and similar parts shall be regularly inspected after the installation is initially placed in operation and as required. (Monthly inspections are recommended.) All broken, defective, and worn parts shall be repaired or replaced immediately.

4.4 Car-Arresting-Device Test. Before the hoist is placed in service and every four months thereafter, a car-arresting-device test shall be performed in accordance with 11.9.6.

4.5 Design. All material hoist towers, masts, guys or braces, counterweights, drive machinery supports, sheave supports, platforms, supporting structures and accessories shall be designed by licensed professional engineers.

\section{Design and Construction of Foundations}

Hoist-tower foundations shall be constructed to support the tower's intended live and dead loads safely and shall not exceed the safe bearing capacity of the ground or floor upon which they rest.

\section{Erection}

\subsection{Vertical Alignment. Hoist towers shall be plumb.}

6.2 Guide Rails. The guide rails of hoists shall be of structural metal, or the equivalent, securely fastened, and shall deflect no more than $1 / 4$ inch under normal operation.

\subsection{Grounding. Hoist towers shall be electrically} grounded.

6.4 Hoist-Tower Enclosures. Hoist towers may be used with or without an enclosure on all sides. However, whichever alternative is chosen, applicable conditions in 6.4.1 through 6.4 .3 shall be met:

6.4.1 When a hoist tower is enclosed, it shall be enclosed on all sides for its entire height by a wire-screen enclosure of not less than No. 19 U.S. gage wire or equivalent material, with openings not exceeding $1 / 2$ inch, securely fastened to the tower structure, with openings formed onto each landing.

6.4.2 When a hoist tower is not enclosed, the hoist platform or car shall be totally enclosed as set forth in 11.7 .

6.4.3 For hoists located outside of structures, the enclosures, except those at the lowest landing, may be omitted on the sides where there is no floor or scaffold adjacent to the hoistway. Enclosures on the building 

Table 1

Minimum Sizes of Various Members in Wooden Towers

\begin{tabular}{|c|c|c|c|c|c|c|}
\hline \multicolumn{2}{|c|}{ Capacity } & \multirow{2}{*}{$\begin{array}{l}\text { Height from } \\
\text { Top Down } \\
\text { (ft) }\end{array}$} & \multirow{2}{*}{$\begin{array}{l}\text { Post } \\
\text { Sizes } \\
\text { (in) }\end{array}$} & \multirow{2}{*}{$\begin{array}{l}\text { Horizontal } \\
\text { Tie } \\
\text { Sizes } \\
\text { (in) }\end{array}$} & \multirow{2}{*}{$\begin{array}{l}\text { Diagonal } \\
\text { Brace } \\
\text { Sizes } \\
\text { (in) }\end{array}$} & \multirow{2}{*}{$\begin{array}{l}\text { Maximum } \\
\text { Tie Spacing } \\
\text { (in) }\end{array}$} \\
\hline $\begin{array}{l}\text { Platform } \\
\text { (lb) }\end{array}$ & $\begin{array}{c}\text { Bucket } \\
\left(y d^{3}\right)\end{array}$ & & & & & \\
\hline To $\begin{array}{r}500 \\
500\end{array}$ & - & $\begin{array}{l}\text { Top to } 72 \\
72 \text { to } 198\end{array}$ & $\begin{array}{l}4 \times 4 \\
4 \times 6\end{array}$ & $\begin{array}{l}1 \times 6 \\
2 \times 6\end{array}$ & $\begin{array}{l}1 \times 6 \\
1 \times 8\end{array}$ & $\begin{array}{l}6 \\
6\end{array}$ \\
\hline $\begin{array}{l}1000 \\
1000 \\
1000\end{array}$ & $\begin{array}{l}1 / 4 \\
1 / 4 \\
1 / 4\end{array}$ & $\begin{array}{r}\text { Top to } 72 \\
72 \text { to } 126 \\
126 \text { to } 198\end{array}$ & $\begin{array}{l}4 \times 4 \\
4 \times 6 \\
6 \times 6\end{array}$ & $\begin{array}{l}1 \times 6 \\
2 \times 6 \\
2 \times 6\end{array}$ & $\begin{array}{l}1 \times 6 \\
1 \times 8 \\
1 \times 8\end{array}$ & $\begin{array}{l}6 \\
6 \\
6\end{array}$ \\
\hline $\begin{array}{l}2000 \\
2000 \\
2000\end{array}$ & $\begin{array}{l}1 / 2 \\
1 / 2 \\
1 / 2\end{array}$ & $\begin{array}{r}\text { Top to } 80 \\
80 \text { to } 128 \\
128 \text { to } 208\end{array}$ & $\begin{array}{l}4 \times 6 \\
4 \times 6 \\
6 \times 6\end{array}$ & $\begin{array}{l}2 \times 6 \\
2 \times 6 \\
2 \times 6\end{array}$ & $\begin{array}{l}1 \times 8 \\
1 \times 8 \\
2 \times 6\end{array}$ & $\begin{array}{l}8 \\
8 \\
8\end{array}$ \\
\hline $\begin{array}{l}4000 \\
4000 \\
4000\end{array}$ & $\begin{array}{l}1 \\
1 \\
1\end{array}$ & $\begin{array}{l}\text { Top to } 80 \\
80 \text { to } 128 \\
128 \text { to } 208\end{array}$ & $\begin{array}{l}4 \times 6 \\
6 \times 6 \\
6 \times 8\end{array}$ & $\begin{array}{l}2 \times 6 \\
2 \times 6 \\
2 \times 8\end{array}$ & $\begin{array}{l}2 \times 6 \\
2 \times 6 \\
2 \times 6\end{array}$ & $\begin{array}{l}8 \\
8 \\
8\end{array}$ \\
\hline
\end{tabular}

\section{Requirements for Inside Hoists}

10.1 Enclosure. The sides of the hoistways not used for entrances shall be enclosed on each floor for their entire height with wire mesh or equivalent material and reinforced to withstand a horizontal force of 100 pounds per square foot, applied at any point. The openings in the mesh shall not exceed $1 / 2$ inch.

10.2 Covering at Cathead. Protective covering of heavy planking shall be provided at the cathead of all hoists to prevent objects falling down the hoistway.

\section{Hoist Platforms and Cages}

11.1 Prohibition of Riders. Workmen shall be prohibited from riding the hoist platform except for authorized inspection and maintenance. A sign shall be posted on the car frame or enclosure: NO RIDERS ALLOWED.

11.2 Rolling Equipment. When wheelbarrows or other rolling equipment are transported, they shall be held securely in place on the hoist platform. The platform shall be level with the landing prior to loading or unloading rolling equipment.

11.3 Overhead Protection. Overhead protective covering of 2-inch planking, 3/4-inch plywood, or other solid material of equivalent strength shall be provided on the top of every material hoist cage or platform to prevent objects falling on the workmen loading or unloading the hoist.

11.4 Hinged Covers. The protective covering on the top of the cage or platform may be made in hinged sections that can be raised when long material is hoisted. Hinged covers shall be designed and constructed so that they cannot strike any part of the tower.
11.5 Securing Long Material. When a cage or platform is used for long material, the several pieces of the material shall be securely fastened together and made fast to the cage or platform so that no part of the load can fall or project beyond the sides of the cage or platform.

11.6 Slip-Resistant Floors. Platform floors covered with metal shall have a slip-resistant surface.

11.7 Platform Enclosure. When a hoist tower is not enclosed, the hoist platform shall be totally enclosed (caged) on all sides, including the roof, for the full distance between the floor and the cage top. The walls and the gates of the cage shall be constructed of 2-inch No. 14 U.S. gage wire mesh, or the equivalent. The hoist platform enclosure will include the required gates for loading and unloading.

11.8 Load-Rating Plate. A load-rating plate shall be attached to the hoist to indicate the live load capacity of:

(1) The platform with the cage installed

(2) The bucket and supporting structure

11.9 Car-Arresting Safety Device. A car-arresting device shall be used with a material platform or a platform installed in conjunction with a bucket, and it shall conform to the requirements given in 11.9.1 through 11.9.6. However, under no circumstances shall it be required to satisfy the requirements of American National Standard Safety Requirements for Personnel Hoists, A1 0.4-1973.

11.9.1 The car-arresting device, when engaged, shall be capable of stopping and holding the platform with its rated load.

11.9.2 The car-arresting device shall be securely attached to the frame of the platform or bucket in such manner that the platform will not become separated from the car-arresting device under the conditions cited in 11.9.1. 

11.9.3 Any platform used with a car-arresting device shall be capable of meeting the conditions cited in 11.9.1 without resultant failure or loss of its load.

11.9.4 Any material hoist structure, including tower components, guide rails and their attachments, and any parts affected by the action of the car-arresting device, when subjected to the conditions cited in 11.9.1 shall sustain the platform with its rated load without structural failure.

11.9.5 The car-arresting device shall be activated by a positive means in the event of car suspension failure, and when engaged shall be released only by raising the platform from the stopped position.

11.9.6 Car-arresting devices shall be tested in accordance with 11.9.6.1 through 11.9.6.3.

11.9.6.1 For rope-supported cars the test shall be conducted in the following manner:

(1) Pull a loop in the lifting rope and attach the test rope to each side of the loop above the bucket or platform

(2) Raise platform or bucket to allow the load to be supported by the test rope

(3) Cut the test rope to allow the load to fall and activate the car-arresting device

11.9.6.2 For car suspension other than rope supported, the test shall be conducted by creating an overspeed condition of the car.

11.9.6.3 Structural components shall be inspected for damage after the test and before the hoist is placed in operation again.

\section{Buckets}

12.1 Work in the Pit. When men are required to work in the pit, the bucket shall be shored on two sides with timbers, or their equivalent, of sufficient strength to support the bucket. Timbers shall not protrude into an adjacent hoistway.

12.2 Prohibition of Riding. Workmen shall be prohibited from riding the bucket except for authorized inspection and maintenance.

\section{Booms}

13.1 Fixed Radii. All booms mounted on a material hoist tower shall operate at fixed radii.

13.2 Live Booms. Live booms shall be prohibited.

13.3 Boom Location. Booms shall be located so that at no time will a boom or its load be directly above the hoist operator's normal working position.

\section{Material Hoist Wire Rope and Sheaves}

14.1 Breaking Strength. All hoisting rope shall be of such breaking strength as to provide a minimum factor of safety of 7 . The factor of safety $(F)$ shall be calculated by the following formula:

$F=\frac{S N}{W}$

where

$S=$ Manufacturer's rated breaking strength of one rope

$N=$ Number of parts of rope under load

$W=$ Maximum gross load

\subsection{Wire Rope Inspection}

14.2.1 Periods of Inspection. Inspection periods shall be set up for each material-hoist wire rope. The frequency of inspection shall be determined by consideration of environment, degree of hazard to materials, frequency of operation, and the frequency with which the rope is subjected to its capacity limits. Inspections shall be made before initial use and not less of ten than once each month thereafter.

14.2.2 Method of Inspection. The entire working length of the wire rope shall be inspected. Thorough inspection shall be made of the rope sections that pass over sheaves, drums, or contact saddles, or which make opposing turns. The rope close to end attachments shall be carefully inspected.

14.2.3 Inspection of Wire Rope on Idle Equipment. The wire rope on equipment that has been idle or shut down for a period of one month or more shall be completely inspected prior to operation.

14.2.4 Inspection of Surfaces Contacted by Wire Rope. Sheaves, guards, guides, drums, flanges, and other surfaces contacted by wire rope during operation shall be examined at the time of inspection. Any condition harmful to the rope in use at the time shall be corrected.

14.3 Wire Rope Removal and Replacement

14.3.1 Wire rope with one or more of the following defects shall be removed or replaced immediately:

(1) Corrosion.

(2) Broken wires:

(a) One or more valley breaks. (A valley break is a wire break occurring in the valley between two adjacent strands.)

(b) Six randomly distributed broken wires in one rope lay. (A rope lay is the length of rope along which one strand makes a complete revolution around the rope.)

NOTE: If a broken wire or wires are localized in the end attachment of an operating rope and this condition may be eliminated by making a new attachment, this may be done instead of replacing the entire rope. 

(3) Abrasion: Abrasion, scrubbing, flattening, or peening causing loss of more than one-third of the original diameter of the outside wires.

(4) Kinking: Severe kinking, crushing, bird caging, or other damage resulting in distortion of the rope structure.

(5) Heat damage: Evidence of any heat damage resulting from a torch or caused by contact with electrical wires.

(6) Reduction of rope diameter: Reduction from nominal diameter of more than $3 / 64$ inch for diameters up to and including $3 / 4$ inch, of more than $1 / 16$ inch for diameters $7 / 8$ to $1-1 / 8$ inches, and of more than $3 / 32$ inch for diameters $1.1 / 4$ to $1.1 / 2$ inches. (Marked reduction in diameter indicates deterioration of the core.)

14.4 Wire Rope Installation. Hoisting ropes shall be installed in accordance with the wire rope manufacturer's recommendations. The hoisting ropes shall be secured to the drum, counterweight, or platform by clamps or by an approved equivalent means.

\subsection{Drums and Sheaves}

14.5.1 Pitch Diameter. Pitch diameters of druns shall be a minimum of $24 X$ the nominal rope diameter. The drum flange shail extend at least 2 inches radially beyond the last layer of rope when the platform, cage, or bucket is at the highest point of travel.

14.5.2 Rope Turns on Drum. The winding drum shall have not less than three turns of rope when the platform, cage, or bucket is at the lowest point of travel.

14.5.3 Wire Rope Grade. All hoisting wire rope shall be improved plow steel grade or stronger, and equal in flexibility to $6 \times 19$ classification wire rope. The joining of hoisting ropes by splicing is prohibited.

14.5.4 Clearance at Cathead. There shall be at least 4 feet of clearance between the cathead sheave and the hoisting-rope fastening on the platform, cage, or bucket when either is at the uppermost terminal or landing.

\subsubsection{Sheave Groove}

14.5.5.1 The arc of the bottom of the sheave groove shall be smooth and concentric with the bore or shaft of the sheave. The centerline of the groove shall be in a plane perpendicular to the axis of the bore or shaft of the sheave above.

14.5.5.2 Sheave grooves shall be machined or cast, providing the bottom of the groove has a radius subtending an arc of 150 degrees and conforms to Table 2.

14.5.6 Minimum Sheave Diameter. Load-bearing sheaves for wire rope shall be grooved to accommodate the rope and shall have a diameter at least $20 X$ that of the wire rope. For minimum tread diameter of sheaves
Table 2

Groove Radii for New and Reconditioned Sheave Grooves

\begin{tabular}{ccc}
\hline $\begin{array}{c}\text { Wire Rope } \\
\text { (nom dia) }\end{array}$ & $\begin{array}{c}\text { Groove } \\
\text { (min) }\end{array}$ & $\begin{array}{c}\text { Root } \\
\text { Radius } \\
\text { (max) }\end{array}$ \\
\hline $1 / 4$ & 0.140 & 0.150 \\
$5 / 16$ & 0.170 & 0.180 \\
$3 / 8$ & 0.205 & 0.215 \\
$1 / 2$ & 0.265 & 0.275 \\
$5 / 8$ & 0.330 & 0.340 \\
$3 / 4$ & 0.390 & 0.400 \\
$7 / 8$ & 0.460 & 0.475 \\
1 & 0.525 & 0.540 \\
$1-1 / 8$ & 0.585 & 0.600 \\
$1-1 / 4$ & 0.655 & 0.670 \\
\hline \hline
\end{tabular}

Table 3

Minimum Ratio of Rope Diameter to Sheave Tread Diameter

\begin{tabular}{cc}
\hline $\begin{array}{c}\text { Diameter } \\
\text { of Hoisting } \\
\text { Rope } \\
\text { (in) }\end{array}$ & $\begin{array}{c}\text { Minimum } \\
\text { Tread Diameter } \\
\text { of Sheaves* } \\
\text { (in) }\end{array}$ \\
\hline $1 / 4$ & 5 \\
$5 / 16$ & $6-1 / 2$ \\
$3 / 8$ & $7-1 / 2$ \\
$1 / 2$ & 10 \\
$5 / 8$ & $12-1 / 2$ \\
$3 / 4$ & 15 \\
$7 / 8$ & $17-1 / 2$ \\
1 & 20 \\
$1-1 / 8$ & $22-1 / 2$ \\
$1-1 / 4$ & 25 \\
\hline \hline
\end{tabular}

* Based on $20 \mathrm{X}$ rope diameter.

see Table 3. (The diameter of a sheave is measured at the bottom of the grooves.)

14.5.7 Prohibition of Fiber Rope Sheaves. Sheaves intended for use with fiber rope shall not be used with wire rope.

14.5.8 Defective Sheaves. Defective and worn sheaves that may cause equipment failure or damage to the wire rope shall be replaced. If pillow blocks are used, they shall be mounted on top of beams and securely bolted. Open bearings shall not be used.

14.5.9 Prohibition of Snatch Blocks. No snatch blocks or hood-type sheaves shall be used on any hoist tower.

14.5.10 Sheave Material. All sheaves shall be of steel, or the equivalent.

14.5.11 Sheave Bearings. All sheave bearings shall have ball or roller bearings, or bearings lined with babbitt or other equivalent bearing metal.

14.5.12 Bearing Lubrication. Sheave bearings shall be provided with adequate means for lubrication.

14.5.13 Bolt and Pin Specification. All bolts and 

pins securing sheaves and drums shall comply with AISC S310, Feb 12, 1969 (see 2.3).

\section{Wire Rope Fastenings}

15.1 Wire Rope Attachment. Ropes shall be securely attached with drop-forged steel wire rope clips and thimbles or other approved equivalent fastening devices. When extra wire rope is carried on top of the frame of the hoist platform, a drum and clamp tiedown or equivalent-type anchoring device, which will not damage the wire rope, shall be used.

15.2 Clip Number, Spacing, and Torque. The minimum number of wire rope clips, spacing of clips, and tightening torque of clips shall be in accordance with the instructions of the clip manufacturer.

15.3 Retightening of Clips. After the rope has been in use for a maximum of one month, at each inspection the nuts on all wire rope clips shall be retightened to the torque recommended by the clip manufacturer. Clips work loose because of oscillating tension stresses as well as vibration, and shall be checked periodically for tightness.

\section{Hoisting Machines}

16.1 Capacity. Hoisting machines shall be designed, installed, and maintained to raise and lower vertically the rated load plus the weight of equipment and ropes.

16.2 Brakes. The hoisting machine shall be equipped with brakes capable of stopping and hoiding $125 \%$ of its rated hoisting capacity under all operating conditions.

16.3 Stability. The hoisting machine shall be secured in position so as to prevent lateral movement, shifting, or dislodgment.

16.4 Location and Arrangement. The location and arrangement of the hoisting machine, tower, and related sheaves shall be such as to assure proper wrapping of the wire rope on the drum to prevent "overriding," fouling, improper spacing, or any other condition that will cause damage to the wire rope or hoisting machine.

16.5 Manning. The hoisting machine shall be attended by the operator, who shall not leave the controls while the load is suspended or the master clutch is engaged.

16.6 Blocking and Bracing. Blocking and bracing shall be provided between the hoisting machine and the tower to prevent the transmission to the tower of any unbalanced lateral forces resulting from the pull of the hoisting ropes.

16.7 Machinery Platform Rails: When hoisting machinery is set on an elevated platform, the platform shall be designed and constructed to support the intended load without failure and shall be provided with guardrails and toeboards that conform to American National Standard Safety Requirements for Scaffolding, A10.8-1969.

16.8 Hoisting Rope Guards. Hoisting ropes within 7 feet of floor or ground shall be guarded by an enclosure or fence.

16.9 Gear Guards. All gears on hoisting machines shall be guarded in conformity with American National Standard Safety Standard for Mechanical Power Transmission Apparatus, B15:1-1972.

16.10 Prohibition of Multiple Unit Operation. No more than one platform, cage, boom, or bucket operated by any one hoisting machine shall be in motion at the same time.

16.11 Brake Drums. Brake drums shall be kept free of oil, grease, or any other substance that reduces their efficiency.

16.12 Mechanical Brakes. Mechanical brakes shall be so installed as to stop movement of the winding drum and shall be equipped with a positive acting device, designed as part of the hoist, that will hold the brake in the engaged position.

16.13 Ratchet and Pawl. Each friction-clutch-driven winding drum hoisting machine shall be equipped with an effective pawl and ratchet capable of holding the rated load capacity when it is suspended.

16.14 Engine Exhaust. Internal-combustion-engine exhaust pipes shall be arranged to exhaust away from workmen and from combustible materials. A muffler shall be installed to reduce the noise.

16.15 Fuel Cans. Safety cans shall be used for handling fuel for internal-combustion engines. When gravity-type fuel systems are used, a cutoff valve shall be installed between the internal-combustion engine and the fuelsupply tank.

16.16 Refueling Precautions. Open lights, flames, or spark-producing devices shall be kept at least 25 feet away while internal-combustion engines are being refueled, and no person shall smoke or carry lighted smoking materials in the immediate area. The engine shall be stopped during refueling.

16.17 Fire Extinguishers. An all-purpose fire extinguisher for Class A, B, and C fires, which meets the 

requirements of American National Standard Installation of Portable Fire Extinguishers, Z112.1-1974 (2nd ed) (NFPA No. 10-1974), shall be part of the hoisting equipment.

16.18 Hoisting during Maintenance. Material hoisting shall not be carried on while men are engaged in erection, maintenance, or repair of the hoisting machine.

16.19 Daily Inspection. All hoisting machines, including brakes, gears, levers, and wire rope, shall be visually inspected daily. All broken, worn, or defective parts shall be repaired or replaced when discovered.

16.20 Electrical Equipment Protection. Electrical equipment shall be grounded in conformance with American National Standard National Electrical Code, C1.1971 (NFPA No. 70).

16.21 Direct-Coupled Machine Brakes. Electric-motor, direct-coupled-drive hoisting machines shall be provided with a mechanical automatic motor brake, or an equivalent device, to hold the load automatically in case of power failure.

16.22 Rack and Pinion Drives. For rack and pinion drives the pinions and rack shall be of steel with a minimum safety factor of 4 . The drive may be located on the counterweight or on the platform.

16.23 Hoisting Machine Location. The hoisting machine shall be located so that no part of it or its enclosure extends into the hoistway.

16.24 Power Failure Disconnect. Electric-motor-operated hoists shall be provided with a device to automatically disconnect all motors from the line upon power failure and not permit any motor to be restarted until the controller is brought to the off position.

16.25 Machine Controls. Hoisting machines of more than one-drum capacity shall have bank or console controls.

\section{Operator Qualification}

When required by law, each operator, before starting the job and at least annually thereafter, shall obtain a physician's certificate of fitness.

\section{Protection of Operator}

18.1 Overhead Protection. The operator of a hoisting machine shall be provided with overhead protection equivalent to tight planking not less than 2 inches thick.
The support for the overhead protection shall be of equal strength.

18.2 Enclosure. The area occupied by the hoisting machine and its operator shall be protected from the elements and shall be heated in cold weather.

18.3 Prohibition of Open-Flame Heaters. No openflame heaters shall be allowed inside any operator's enclosure. When other types of heaters are necessary, they shall be properly vented.

18.4 Heater Requirements. Heating systems shall be installed in compliance with American National Standard Safety Requirements for Temporary and Portable Space Heating Devices and Equipment Used in the Construction Industry, A10.10-1970.

18.5 Lighting. Lighting adequate for maintenance and operation of the hoisting machine shall be provided, but in no case shall it be less than 5 footcandles.

18.6 Glass. All giass used in the operator's enclosure shall be safety glass, or the equivalent.

\section{Signal Systems}

19.1 Hand Signals. Hand signals may be used on a single drum hoist when the hoist tower does not exceed 50 feet in height provided that the signals are clearly visible to the operator at all times.

19.2 Electrical Communication. A closed-circuit electrical communication system shall be used when the height of the tower exceeds 50 feet and on all multiple well towers regardless of height.

19.3 Speaker Location. The electrical intercommunication system shall be a two-way system with a speaker located at the hoist operator's position so that he can hear from and talk to each station.

19.4 Electrical System Protection. All wires and devices used in connection with the signal system shall be protected from the weather.

\section{Indicators}

A positive system shall be used to indicate when the load has reached specific positions.

\section{Electric Motors}

21.1 Motor Installations. Motor installations shall be made in accordance with provisions of applicable local 

codes and American National Standard National Electrical Code, C1-1971 (NFPA No. 70-1971).

21.2 Switches. Only enclosed switches with grounded cases and fuses or circuit breakers shall be used.

21.3 Control Panels. Control panels shall be enclosed, and unauthorized persons shall not be permitted access to such panels.

21.4 Emergency Electrical Cutoff. An emergency means shall be provided within reach of the operator to cut off the electric power.

\section{Landings and Runways}

22.1 Design. Landing platforms and runways that connect the hoistway or tower to the building shall be designed and constructed to sustain the maximum intended load without failure. Metal-covered floors or platforms shall have slip-resistant surfaces.

22.2 Railings. Railings and toeboards that conform to American National Standard Safety Requirements for Scaffolding, A10.8-1969, shall be placed on the open sides of runways connecting the tower to the structure.

22.3 Overhead Protection. All landing platforms where workmen may be exposed to falling objects shall be provided with a solid overhead protection composed of 2 -inch planking or the equivalent.

22.4 Barricades. A barricade shall be required at each landing. The barricade shall extend a minimum distance of 6 feet laterally along the outer edge of the landing from each side of the hoistway or runway and shall extend a minimum distance of 36 inches above the level of the landing, runway, or structu re floor. The material used for the barricade shall be of No. 19 U.S. gage wire mesh, or the equivalent, with openings not exceeding $1 / 2$-inch.

22.5 Working Platforms. Working platforms of ample size and strength, and railings and toeboards that conform to American National Standard A10.8-1969 shall be built at each level where men are required to work, such as bucket dumps and hopper headers.

22.6 Housekeeping. Access to and the area around landings and the hoisting machine shall be kept clear of rubbish and waste material.

22.7 Prohibition of Material Storage. Materials shail not be stored on landing platforms or landing runways.

\section{Capacity Statement and Design}

23.1 Design. All material hoist towers, masts, etc, shall be of such design that maximum intended loads will not stress any members beyond safe limits established by applicable engineering formulas.

23.2 Booms and Auxiliary Equipment Loads. The design shall provide ample strength for loads imposed by the use of booms attached tc a tower or mast. Where, in addition to the loaded platform or bucket, auxiliary equipment or other load-bearing devices are supported by the tower, the tower shall be built to withstand these additional loads and stresses safely. The rated load, specified by the manufacturer, shall not be exceeded.

\section{Revision of American National Standards Referred to in This Document}

When the following American National Standards referred to in this document are superseded by a revision approved by the American National Standards Institute, Inc, the revision shall apply:

American National Standard Safety Requirements for Personnel Hoists, A10.4-1973

American National Standard Safety Requirements for Scaffolding, A10.8-1969

American National Standard Safety Requirements for Temporary and Portable Space Heating Devices and Equipment Used in the Construction Industry, A10.1C1970

American National Standard Safety Code for Dumbwaiters, Escalators, and Moving Walks, A17.1-1971. including Addenda A17.1a-1972, A17.1b-1973, and A17.1c-1974

American National Standard Safety Standard for Manlifts, A90.1-1969, including Supplement A90.1a-1972

American National Standard Safety Standard for Mechanical Power Transmission Apparatus, B15.1-1972

American National Standard National Electrical Code, C1-1971 (NFPA No. 70-1971)

American National Standard Installation of Portable Fire Extinguishers, Z112.1-1974 (2nd ed) (NFPA No. 10-1974) 

A. 3 Excerpts ${ }^{*}$ from

Safety Requirements for

Concrete Construction and Masonry Work

American National Standard ANSI A10.9-1970

American National Standards Institute

New York, New York

The excerpts from ANSI A10.9-1970 are reproduced herein by permission of the American National Standards Institute, 1430 Broadway, New York, New York 10018. 


\section{Formwork Construction}

6.1 General. Section 6 deals with the design, releasing, and raising of formwork. It also deals with the design, fabrication, and handling of forms. Formwork must be adequately designed, erected, supported, braced, and maintained so that it will safely support all vertical and lateral loads that may be applied until such loads can be supported by the concrete structure.

6.1.1 Good housekeeping shall be maintained at all times, and striz ped lumber and materials intended for reuse should be cleaned of nails and wire and removed from the immediate work area.

6.1.2 Lumber, concrete, form hardware, and other materials shall not be permitted to accumulate on walers. scaffolds, and walkways.

6.1.3 Fire protection shall be provided in areas where wood forms and other combustible materials are being used.

6.1.4 Watchmen or fireguards shall be provided where salamanders or similar heaters are used to provide winter protection.

6.1.5 Where tarpaulins or other flammable materials are used to form protective enclosures for winter protection, the material shall be fire-resistant and installed so as to prevent contact with the heating unit.

6.1.6 Form supports and wedges shall be checked during concrete placement to prevent distortion or failure.

\subsection{Form Design}

6.2.1 Any form, regardless of size, shall be planned in every particular and designed and constructed with an adequate factor of safety. In addition to computable loading, additional form pressures may result from impact during concrete placement, sudden lowering of temperatures retarding the set and increasing the liquid head or static pressure, vibrations of the form or concrete, uneven stressing resulting from failure or weakening of form members, or impact from concrete buckets or placing equipment. As a result, an adequate factor of safety is required to offset these unpredictable conditions.

6.2.2 The thoroughness of planning and design shall be governed by the size, complexity, and intended use of the form. Form. work which is complex in nature or which will be subjected to unusually high concrete pressures shall be designed or approved for use by an engineer or experienced form designer.

6.2.3 Unit stresses for use in the design of formwork, exclusive of accessories, should conform to applicable codes and specifications in Formwork for Concrete, American Concrete Institute Special Publication No. 4, 1969. When fabricated formwork, shoring, or scaffolding units are used, manufacturers' recommendations for allowable loads may be followed if supported by test reports or successful experience records. 

6.2.4 Forms of a temporary nature with limited reuse shall conform to allowable stresses as specified in appropriate design codes or specifications for temporary structures or for temporary loads on permanent structures, as approved by the authority having jurisdiction.

6.2.5 Where a considerable number of reuses are intended and where the forms to be used are fabricated from material such as steel, aluminum, or magnesium, it is recommended that the formwork be designed as a permanent structure carrying permanent loads.

6.2.6 The minimum safety factors shown in Table 1, which are based on ultimate strength of the accessory, shall be used in the design and use of formwork hardware and accessories.

6.2.7 For safety considerations relating to the design of shores, see Section 8, Vertical Shoring.

\subsection{Loads}

6.3.1 Vertical Loads. Vertical loads consist of a dead load plus an allowance for live load. The weight of formwork together with the weight of freshly placed concrete is dead load. The live load consists of the weight of workmen, equipment, runways, and impact, and shall be computed in pounds per square foot (psf) of horizontal projection. (See 8.1.5.)

6.3.2 Lateral Loads. Braces and shores shall be designed to resist all foreseeable lateral loads such as wind, cable tensions, inclined supports, impact of placement, and starting and stopping of equipment. The assumed value of load due to wind, impact of concrete, and equipment acting in any direction at each floor line shall not be less than 100 pounds per lineal foot of floor edge or 2 percent of total dead load of the floor, whichever is greater. Wall forms shall be designed for a minimum wind load of $10 \mathrm{psf}$, and bracing for wall forms should be designed for a lateral load of at least 100 pounds per lineal foot of wall, applied at the top. Walls of unusual height require special consideration.

6.3.3 Special Loads Formwork shall be designed for all special conditions of construction likely to occur, such as unsymmetrical placement of concrete, impact of machinedelivered concrete, uplift, and concentrated loads.

Table 1

Design Capacities of Formwork Accessories* $\ddagger$

\begin{tabular}{|c|c|c|}
\hline Accessory & Safety factor & Type of construction \\
\hline Form tie & $\begin{array}{l}1.5 \\
2.0\end{array}$ & $\begin{array}{l}\text { Light formwork; or ordinary single lifts at grade and } 16 \mathrm{ft} \text { or less above grade } \\
\text { Heavy formwork; all formwork more than } 16 \mathrm{ft} \text { above grade or unusually } \\
\text { hazardous }\end{array}$ \\
\hline Form anchor & $\begin{array}{l}1.5 \\
2.0 \\
3.0\end{array}$ & $\begin{array}{l}\text { Light form panel anchorage only; no hazard to life involved in failure } \\
\text { Heavy forms-failure would endanger life-supporting form weight and con- } \\
\text { crete pressures only } \\
\text { Falsework supporting weight of forms, concrete, working loads, and impact }\end{array}$ \\
\hline Form hangers & $\begin{array}{l}1.5 \\
2.0\end{array}$ & $\begin{array}{l}\text { Light formwork. Design load including total weight of forms and concrete. } \\
\text { with } 50 \text { psf minimum live load is less than } 150 \text { psf } \\
\text { Heavy rormwork; form plus concrete weight } 100 \text { psf or more; unusually } \\
\text { hazardous work }\end{array}$ \\
\hline Lifting inserts & $\begin{array}{l}2.0 \\
3.0\end{array}$ & $\begin{array}{l}\text { Tilt-up panels } \\
\text { Precast panels }\end{array}$ \\
\hline $\begin{array}{l}\text { Expendable strand } \\
\text { deflection devicest }\end{array}$ & 2.0 & Pretensioned concrete members \\
\hline $\begin{array}{l}\text { Re-usable strand } \\
\text { deflection devices }\end{array}$ & 3.0 & Pretensioned concrete members \\
\hline
\end{tabular}

- Design capacities guaranteed by manufacturers may be used in lieu of tests for uitimate strength tThese safety factors also apply to pieces of prestressing strand which are used as part of the deflection device.

\$This Table is reproduced from American National Standard Recommended Practice for Concrete Formwork, A145.11968 (ACI 347-68). Copyright 1967 by the American Concrete Institute. Reprinted by permission. 

6.3.4 Construction Loads. Imposition of any construction loads on the partially compheted structure shall not be permitted unless such loading has been considered in the design and approved by the engineer-architect.

\subsection{Placing and Removal of Forms}

6.4.1 When moved or raised by crane, cableway, A-frame, or similar mechanical device, forms shall be securely attached to wire rope slings having a minimum safety factor of 5. Use of No. 9 tie wire, fiber rope, and similar makeshift lashing shall be prohibited.

6.4.2 Taglines shall be used in moving panels or other large sections of forms by crane or hoist.

6.4.3 All hoisting equipment, including hoisting cable used to raise and move forms, shall have a minimum safety factor incorporated in the manufacturer's design, and the manufacturer's recommended loading shall not be exceeded. Field- or shop-fabricated hoisting equipment shall be designed or approved by a registered professional engineer, incorporating a minimum safety factor of 5 in its design. Panels and built-up form sections shall be equipped with metal hoisting brackets for attachment of slings.

6.4.4 Forms intended for use where there is a free fall of over ten feet shall be equipped with adequate scaffolding and guardrails, or employees working on the forms shall be required to wear safety belts during forming and stripping operations. Form scaffolding shall be designed and constructed as provided in Section 7 unless an alternative design is specifically approved by the authority having jurisdiction.

6.4.5 Vertical forms being raised or removed in sections shall not be released until adequately braced or secured. Likewise, overhead forms shall not be released until adequately braced or secured.

6.4.6 Workmen or others at lower levels shall be protected from falling materials, and appropriate warning signs shall be erected along walkways.

6.4.7 Forms shall not be removed prematurely. The concrete should be adequately set in order to permit safe removal of the forms, shoring, and bracing. Engineer's specifications and local building codes shall be adhered to in determining the length of time forms should remain in place following con- crete placement. In addition, tests shall be made on field-cured concrete specimens in order to insure that concrete has obtained sufficient strength to safely support the load prior to removal of forms.

6.4.8 When field operations are not controlled by the engineer's specifications or local building codes, under ordinary conditions form and supports shall remain in place for not less than the periods of time shown in Table 2. These periods represent cumulative number of days or fractions thereof, not necessarily consecutive, during which the temperature of the air surrounding the concrete is above $50^{\circ} \mathrm{F}$. If high-early-strength concrete is used, these periods may be reduced as approved by the engineer-architect. Conversely, if low-temperature concrete or retarding agents are used, these periods may be increased at the discretion of the engineer-architect.

\subsection{Vertical Slip Forms}

6.5.1 Slip forms shall be designed and constructed, and the form movement carried out, under the immediate supervision of a person or persons experienced in slip form design and operation. Drawings prepared by a qualified engineer, showing the jack layout, formwork, working decks, and scaffolding, shall be available at the jobsite, and followed.

6.5.2 The steel rods or pipe on which the jacks climb or by which the forms are lifted shall be especially designed for the purpose. Such rods must be adequately braced where not encased in concrete.

6.5.3 Jacks and vertical supports shail be positioned in such a manner that the vertical loads are distributed equally and do not exceed the capacity of the jacks.

6.5.4 The jacks or other lifting devices should be provided with mechanical dogs or other automatic holding devices to protect against failure of the power supply or the lifting mechanism.

6.5.5 Lifting shall proceed steadily and uniformly and shall not exceed the predetermined safe rate of lift. A jacking system, which provides precise, simultaneous movement of the entire form in small preselected increments, is recommended for large structures.

6.5.6 Lateral and diagonal bracing of the forms shall be provided to prevent excessive 



1

1
$j$ 